\title{
Effectiveness of Google Classroom and Edmodo in online learning during the COVID-19 pandemic among pharmacy students of Health Polytechnic of Health Ministry Kupang, Indonesia
}

\author{
Priska Ernestina Tenda, Maria Hilaria, Muhamad Satria Pua Upa, Emanuel Gerald Alan Rahmat \\ Health Polytechnic of Health Ministry Kupang, Indonesia
}

\author{
Keywords \\ Edmodo \\ Effectiveness \\ Google Classroom \\ Online learning
}

\section{Correspondence}

Priska ernestina tenda

Health Polytechnic

Health Ministry Kupang

Indonesia

priskatendamola77@gmail.com

\begin{abstract}
Objective: This study aims to determine the effectiveness of using Google Classroom and Edmodo in online learning during the Covid-19 pandemic. Method: This research is quantitative research. The sample was pharmacy students of the Health Polytechnic of Ministry of Health in Kupang of 2019 and 2020 cohort, with a total of 145 people. Data were collected using a questionnaire. Results: One hundred and twelve (72\%) students stated that the use of Google Classroom in online learning during the Covid-19 pandemic had been effective, thirty-two (22\%) students stated that the learning was very effective, and eleven (6\%) students stated that the learning was not effective because they were confused by the available features. They also need a stable internet network, especially when downloading learning video materials. Student assessments using the Edmodo learning media showed one hundred and one (69\%) students said it was effective, twenty-six (18\%) students said it was very effective, and eight (13\%) stated that it was not effective because of difficulty of reading features in English and there was no direct online syntax available on Edmodo. Conclusion: The results showed that Google Classroom and Edmodo could be effectively applied in online learning during the COVID-19 pandemic.
\end{abstract}

\section{Introduction:}

The ongoing COVID-19 pandemic has caused losses globally, not only in the economic sector but also in education, especially in universities. To prevent the spread of COVID-19, the Government of Indonesia issued a circular letter Number 1 of 2020, encouraging universities to hold online teaching and learning processes from home (Kemdikbud, 2017). With the circular letter, Health Polytechnic of Health Ministry, Kupang, Indonesia, which previously held face-to-face learning, changed learning patterns during the COVID19 pandemic and shifted to online learning to prevent or minimise the spread of COVID-19 at Health Polytechnic of Health Ministry, Kupang, Indonesia.

Online learning is a process performed through online learning applications, platforms, and social networks without the need for face-to-face learning. All forms of topics are distributed online, with communication and tests are also done online. Several applications are available for online learning, such as Google Classroom and Edmodo.

Google classroom is a mixed learning media facility for the scope of education that can make it easier for teachers to create, share, and classify each paperless assignment and a popular online learning platform that allows students to attend online classes (Gregory Corbyn, 2019). Another online learning medium, Edmodo, is a multi-platform learning management system that is simple, easy to use, and provides useful functions for students and teachers to interact online outside the classroom. Edmodo can be accessed via web browsers and smartphone applications (IOS and Android) (Charoenwet \& Christensen, 2016). Google Classroom and Edmodo allow teachers to create virtual 
classrooms such as paperless assignments, assignment submissions, and grading. Additionally, these two online learning platforms can be accessed for free via mobile phone, PC, laptop, and tablet (Alim et al., 2019). Several studies have shown that Google Classroom and Edmodo are very helpful and effective in facilitating the learning process and improving student learning outcomes at UIN Syarif Hidayatullah Jakarta (Fauzan \& Arifin, 2019).

With the current global situation of the COVID-19 pandemic limiting movement and social interaction, Google Classroom and Edmodo are recommended, as these two platforms would help students and lecturers stay connected, work together, create and complete assignments, perform assessments, and share lecture notes (Charoenwet \& Christensen, 2016). Google Classroom and Edmodo have shown to be effective in virtual learning because students find it easy to use, and also in terms of displays and access to announcements, materials, and assignments.

Based on the literature review, Google Classroom and Edmodo are effective in improving teaching and learning activities. However, empirical studies that explored the effectiveness of Google Classroom and Edmodo implementation in online learning activities at universities in Indonesia are still limited, especially in pharmacy education and medical and other health professions. Therefore, this study aimed to determine the effectiveness of Google Classroom and Edmodo in online learning during the COVID-19 pandemic among students of the Pharmacist Study Programme of Health Polytechnic of Health Ministry, Kupang, Indonesia.

\section{Method}

This research, conducted in May 2021, used a quantitative descriptive design. The research sample consisted of students from the academic years 2019 and 2020 of the Pharmacist Study Programme of Health Polytechnic of Health Ministry, Kupang, who met the inclusion criteria (i.e. active students or not on leave and taking online learning). The study protocol has been approved by the ethics committee of Health Polytechnic of Health Ministry, Kupang, Indonesia (reference LB.02.01/1/179/2021).

The number of students who met the inclusion criteria was 145. Data were collected through an online questionnaire after getting students' approval to participate. The questionnaire was anonymous, and confidentiality was guaranteed by the researcher. It included 11 questions on Google Classroom and 17 questions on Edmodo.
All items were rated on a 4-point Likert scale from 1 (Strongly Disagree) to 4 (Strongly Agree). For each question, the average score was considered to assess the effectiveness of Google Classroom and Edmodo as learning media as perceived by the students. The scores of Google Classroom were divided into ineffective (11.00-22.00), average (22.01-33.00), and very effective (33.01-44.00). For Edmodo, the scores were categorised as ineffective (17.00-34.00), average (34.01-51.00), and very effective (51.01-68.00). Data were analysed using univariate analysis, displayed in percentages.

Before the questionnaire was distributed to students, it was reviewed by experts from the learning field to ensure its content validity. Furthermore, its reliability was also tested among 40 students who took part in online learning. The Cronbach's alpha values of Google Classroom and Edmodo were 0.951 and 0.920, respectively, which indicated that the instrument was reliable and could be used for data collection.

\section{Result}

A total of 145 students completed the questionnaire instrument on the use of Google Classroom and Edmodo during the COVID-19 pandemic.

Table I presents more details of the effectiveness of Google Classroom and Edmodo as learning support media. Table I shows that, overall, students gave positive responses to Google Classroom use. The highest mean score (3.43) was for the tools in Google Classroom (the tools help me follow the lectures easily. These results show that students strongly agree that Google Classroom helped them participate in online learning. The lowest mean value (2.51) was for the learning done according to the schedule agreed upon by the lecturer and students. These results indicate that respondents do not agree that courses were delivered on time.

Table II presents student responses regarding Edmodo's performance when used as a learning support medium. Table II shows that, overall, students gave a positive response to Edmodo use. The highest mean score was that students did not feel bored when they read their course on Edmodo (3.25). These results indicate that students really liked using Edmodo in online learning and when reading or doing assignments. The lowest mean value was for feeling upset when answering questions on Edmodo and using it on a mobile phone (2.14). These results indicate that only a few students experienced problems while most of them had no issues answering questions or assignments using Edmodo on a mobile phone. 
Table I: Student response to the effectiveness of Google Classroom

\begin{tabular}{|c|c|c|}
\hline Question items & Mean & SD \\
\hline The tools in Google Classroom make it easier for me to follow the lectures & 3.43 & 0.695 \\
\hline Lecturers convey keywords or clues related to the material to be discussed & 3.19 & 0.556 \\
\hline I understand the material and information conveyed by the lecturer through Google Classroom & 2.93 & 0.814 \\
\hline The lecture material discussed is in accordance with the previous lectures & 3.27 & 0.738 \\
\hline Having deadlines on Google Classroom assignments helps me to work on and submit assignments on time & 3.12 & 0.706 \\
\hline Lecturers make lecture participants involve and actively participate in productive discussions & 2.72 & 0.672 \\
\hline Lecturers are friendly and easy to contact during learning activities & 3.06 & 0.460 \\
\hline I feel comfortable talking and interacting with other participants in learning activities through Google Classroom & 3.05 & 0.649 \\
\hline My point of view is acknowledged by other participants during the learning activities & 2.90 & 0.446 \\
\hline Learning was done according to the lecture schedule that agreed upon by the lecturer and students & 2.51 & 0.636 \\
\hline I am very enthusiastic about participating in learning through Google Classroom & 3.00 & 0.486 \\
\hline
\end{tabular}

Table II: Student responses to the effectiveness of Edmodo

\begin{tabular}{|c|c|c|}
\hline Question Items & Mean & SD \\
\hline I find it is difficult to use Edmodo as a mobile learning application. & 2.74 & 0.644 \\
\hline I am concerned during learning using Edmodo & 2.54 & 0.527 \\
\hline I did not feel bored when I read my course by Edmodo & 3.25 & 0.629 \\
\hline I feel upset when answering questions by Edmodo and using mobile phone & 2.14 & 0.796 \\
\hline I do not trust the authenticity of the information that I get them through Mobile phone and Edmodo. & 2.26 & 0.697 \\
\hline I feel upset in solving exercises and activities using the application of Edmodo for mobile learning. & 2.61 & 0.700 \\
\hline $\begin{array}{l}\text { I see that using Edmodo as a mobile learning application would negatively affect the acquisition of the skills of } \\
\text { reading and writing to me. }\end{array}$ & 2.76 & 0.659 \\
\hline Difficult to store large files on my mobile phone. & 3.19 & 0.461 \\
\hline I think that Edmodo as a mobile learning application does not lead to social isolation for students. & 2.81 & 0.717 \\
\hline I feel that using Edmodo as a mobile learning application does not limit the difficulty of the course. & 3.19 & 0.773 \\
\hline I see the difficulty of organizing discussions or education dialogue through Edmodo. & 3.03 & 0.869 \\
\hline I think that Edmodo is focused on the cognitive side more than technical skills and emotional aspects. & 2.63 & 0.754 \\
\hline I feel that the cons of Edmodo are more than the positives. & 2.52 & 0.774 \\
\hline $\begin{array}{l}\text { The small screen size of mobile phones hinders the process of displaying the information in Edmodo on Mobile } \\
\text { phones. }\end{array}$ & 2.69 & 0.759 \\
\hline I do not find it is difficult to enter the information on the small screen size of a mobile phone. & 3.15 & 0.811 \\
\hline I'm suffering from a poor communication network. & 2.69 & 0.786 \\
\hline I'm having a problem with a low mobile battery continuously. & 3.11 & 0.792 \\
\hline
\end{tabular}

Table III presents student responses to the effectiveness of Google Classroom and Edmodo in learning activities. Table III shows that as many as 104 students (72\%) and 100 students (69\%) reported that Google Classroom and Edmodo were effective in online learning activities, respectively.
Table III: Effectiveness of Google Classroom and Edmodo in learning activities

\begin{tabular}{lcccc} 
& \multicolumn{2}{c}{ Google Clasroom } & \multicolumn{2}{c}{ Edmodo } \\
& $\mathbf{n}$ & $\mathbf{\%}$ & $\mathbf{n}$ & $\mathbf{\%}$ \\
\hline Not & 9 & 6 & 19 & 13 \\
Effective & & & & \\
Effective & 104 & 72 & 100 & 69 \\
Very & 32 & 22 & 26 & 18 \\
Effective & & & & \\
\hline Total & $\mathbf{1 4 5}$ & $\mathbf{1 0 0}$ & $\mathbf{1 4 5}$ & $\mathbf{1 0 0}$ \\
\hline
\end{tabular}




\section{Discussion}

Based on the results of the research above, Google Classroom was an effective learning medium in the Pharmacist Study Programme of Health Polytechnic of Health Ministry, Kupang, Indonesia, especially during the COVID-19 pandemic. These results are in line with the findings of Famukhit, reporting that the Google Classroom application had a simple menu and display, making it easy to use and understand in online learning (Famukhit, 2020). Our results also revealed that Google Classroom was also effective in making it easier for lecturers to convey keywords related to the material to be discussed. These results are in line with those of Dash in 2019, where students reported that Google Classroom provided better access to teaching materials, additional learning resources, and feedback and that it provided easier and more effective access to students in obtaining more information (Dash, 2019). However, this research also showed that Google Classroom was not implemented on time and that the two-way communication process between students and lecturers was also not optimal.

Regarding Edmodo, students of the Pharmacist Study Program of Health Polytechnic of Health Ministry, Kupang, Indonesia, gave positive responses to Edmodo, reporting not feeling bored while reading assignments and the ease of use because Edmodo could support learning content and create interactions between educators and students (Dharmawati, 2017; Rusni, 2017). Edmodo could also increase the interaction between students and teachers. Additionally, students thought that the performance of Edmodo as a learning support medium was very good, in line with previous findings (Basori, 2013; Al-said, 2015). Edmodo was reported to be user-friendly, consistent with the results of Balasubramanian and colleagues (2014), where Edmodo provided the latest information very clearly, not only in displayed learning texts but also in the form of images and videos. However, students also argued that they were less comfortable and usage of Edmodo, finding it difficult to use, contrary to previous findings (Wardani, 2017) reporting that Edmodo was easy to use for learning activities. A possible explanation could be that Edmodo was new for students, and they were not used to it in their daily learning activities.

Based on the research analysis above, there are also some shortcomings in the Google Classroom and Edmodo learning media. Thus, it is better to use them only when necessary and supplement them with additional learning videos or innovative methods from teachers so that students do not get bored and the online learning process is not monotonous. For further research, it is recommended to use a larger sample size involving more study programmes in Indonesia, especially in the fields of pharmacy, medical, and other health professions, and from different perspectives, such as lecturers' perceptions of the effectiveness of using Google Classroom and Edmodo as learning media.

\section{Conclusions}

Based on the results of the study, it can be concluded that the use of Google Classroom and Edmodo is effective in online learning during the COVID-19 pandemic.

\section{References}

Al-said, K. M. (2015). Students' Perceptions of Edmodo and Mobile Learning and their Real Barriers towards them. TOJET: The Turkish Online Journal of Educational Technology, 14(2), 167-180

Alim, N., Linda, W., Gunawan, F., \& Saad, M. S. M. (2019). The effectiveness of Google classroom as an instructional media: A case of state islamic institute of Kendari, Indonesia. Humanities and Social Sciences Reviews, 7(2), 240-246. https://doi.org/10.18510/hssr.2019.7227

Balasubramanian, K., Jaykumar, V., \& Fukey, L. N. (2014). A Study on "Student Preference towards the Use of Edmodo as a Learning Platform to Create Responsible Learning Environment." Procedia - Social and Behavioral Sciences, 144, 416-422.

https://doi.org/10.1016/j.sbspro.2014.07.311

Basori. (2013). Pemanfaatan Social Learning Network "Edmodo" dalam Membantu Perkuliahan Teori Bodi Otomotif di PTM JPTK FKIP UNS. JIPTEK, 6(2), 99-105. https://doi.org/10.20961/jiptek.v6i2.12562

Charoenwet, S., \& Christensen, A. (2016). The effect of Edmodo learning network on students' perception, selfregulated learning behaviors and learning performance. IMSCI 2016 - 10th International Multi-Conference on Society, Cybernetics and Informatics, Proceedings, Imsci, 297-300.

Dash, S. (2019). Google classroom as a learning management system to teach biochemistry in a medical school. Biochemistry and Molecular Biology Education, 47(4), 404-407. https://doi.org/10.1002/bmb.21246

Dharmawati. (2017). Penggunaan Media E-Learning Berbasis Edmodo dalam Pembelajaran English for Business QUERY. Jurnal Sistem Informasi, 1(1), 43-49

Fauzan, F., \& Arifin, F. (2019). The Effectiveness of Google Classroom Media on the Students' Learning Outcomes of Madrasah Ibtidaiyah Teacher Education Department. Al Ibtida: Jurnal Pendidikan Guru MI, 6(2), 271.

https://doi.org/10.24235/al.ibtida.snj.v6i2.5149

Gregory Corbyn. (2019). Google Classroom: 99 Ideas How To Use Google Classroom Effectively. The Ultimate Guide To Learn Google Classroom. Independently Published 
Herlambang, A. D., \& Hidayat, W. N. (2016). Edmodo untuk Meningkatkan Kualitas Perencanaan Proyek dan Efektivitas Pembelajaran di Lingkungan Pembelajaran yang Bersifat Asinkron. Jurnal Teknologi Informasi Dan Ilmu Komputer (JTIIK), 3(3), 180-187.

https://doi.org/10.25126/jtiik.201633193

Kemdikbud. (2017). Surat Edaran Nomor 1 Tahun 2020 tentang Pencegahan Penyebaran Corona Virus Disease (Covid-19) di Perguruan Tinggi. Available at: http://kemdikbud.go.id/main/?lang=id

Rusni, A. (2017). Penggunaan media online. Jom Fisip, 2(1), $1-15$

Wahono, A., \& WIbawa, S. C. (2017). Penerapan Edmodo dengan Model Cooperative Learning pada Mata Pelajaran Sistem Operasi. Jurnal IT-Edu, 1(2), 38-48

Wardani, T. I. (2017). Analisis Model Kemanfaatan dan Kemudahan Teknologi dalam Menggunakan Aplikasi ELearning Edmodo. Jurnal Administrasi Dan Bisnis, 11(2), 177-189. https://doi.org/10.33795/j-adbis.v11i2.28 